\title{
Quantifying Genetic Advance of Kabuli Chickpea Varieties for Yield and Yield Related Traits in Ethiopia
}

\author{
Genet Mengistu* \\ DebreZeit Agricultural Research Center, P.O.Box 32 \\ Bulti Tesso (PhD.) \\ Collage of Agricultural Sciences, Department of Plant Science, Haramaya University, POBox 138, Dire Dawa \\ Asnake Fikre (PhD.) \\ DebreZeit Agricultural Research Center, P.O.Box 32
}

\begin{abstract}
Fourteen Kabuli chickpea varieties released since 1974 were evaluated in 2017 cropping season at Akaki, Chefe Donsa, Debre Zeit, and Jari stations to determine genetic progress in yield and yield associated traits of Kabuli chickpea varieties. The varieties were laid out in a randomized complete block design with three replications. The average rate of increase in grain yield per year over the past 42 years period was $22.35 \mathrm{kgha}^{-1} \mathrm{yr}^{-1}$ with a relative genetic gain of $1.04 \%$ year $^{-1}$, which was not significantly different from zero. The regression of hundred seed weight against the years of release showed significant increase for the last 42 years of improvement in Ethiopia. It showed an annual rate of genetic gain of $0.56 \mathrm{~g} \mathrm{yr}^{-1}$ with a relative annual genetic gain of $4.37 \%$. Number of pods per plant and number of seeds per pod revealed a significant decreasing trend over the past 42 years, which could be a reciprocate to the increased seed size. Plant height, days to flowering, and days to maturity showed nonsignificant trend in the current study. Grain yield showed non-significant positive association with plant height, days to flowering, number of pods per plant and non-significant negative association with days to maturity, number of seed per pod and hundred seed weight. Hundred seed weight was positively and significantly correlated with days to maturity but negatively and significantly correlated with number of pods per plant and number of seeds per pod. Therefore, the Kabuli chickpea improvement program needs special attention to compliment seed size and grain yield by using integrated breeding approach to make rapid progress in developing superior Kabuli chickpea varieties.
\end{abstract}

Keywords: Kabuli chickpea, Grain yield, hundred seed weight, Genetic gain

DOI: $10.7176 / \mathrm{JBAH} / 10-15-04$

Publication date:August $31^{\text {st }} 2020$

\section{INTRODUCTION}

Chickpea (Cicer arietinum L.) is an annual diploid with 16 chromosomes and genome of $740 \mathrm{Mbp}$ (Jain et al., 2013). It is a member of genus Cicer, tribe Cicereae, subfamily Papilionoideae, and family fabaceae (vander Massen, 2007). Chickpea is grown in 54 countries with nearly $90 \%$ of its area covered in developing countries (Guar et al., 2012). Evidence have confirmed that Ethiopia is considered as a secondary center of genetic diversity for chickpea (Kanouni et al., 2011, Rajeev et al, 2019). In Ethiopia, chickpea production area and volume ranks third following Faba bean and haricot bean, while its productivity $\left(2058 \mathrm{kgha}^{-1}\right)$ follows Soybean and Faba bean, respectively (CSA,2018).

Globally chickpea is a highly sought after pulse due to its nutritional value and as an inexpensive source of protein. In addition to having higher protein content, as compared to cereals, it has also essential amount of carbohydrates and oil, minerals like calcium, magnesium, potassium, phosphorous, iron, zinc and manganese (Ibrikci et al., 2003). Chickpea is considered less labor-intensive crop and its production requires less external inputs as compared to cereals .It plays a significant role in improving soil fertility by fixing the atmospheric nitrogen. Mostly, chickpea is consumed as food in several different forms and preparations are determined by ethnic and regional factors (Ibrikci et al., 2003). In the Indian subcontinent, chickpea is split (cotyledons) as 'dhal' and ground to make flour ('besan') that is used to prepare different snacks (Hulse, 1991). In other parts of the world, especially in Asia and Africa including Ethiopia, chickpea is used in stews and soups/salads, and consumed in roasted, boiled, salted and fermented forms. Chickpea seeds are also consumed at green pods stage without any processing. These different forms of consumption provide consumers with valuable nutritional and potential health benefits. Additionally, the straw is an important animal feed supplementing cereal straw.

Chickpea yield improvement is challenging due to the influences of the environment, agronomic practices and genetic factors (Wood and Grusak, 2007). Despite the challenges, breeders have been developing improved varieties over the last several decades. Understanding the changes produced by crop breeding on grain yield and its determinants is important to evaluate the efficiency of past improvement works on the advances in genetic yield potential, and to define future strategies to facilitate further progress. Thus, estimation of genetic progress is a useful indicator that helps breeders to make decisions about what future breeding strategy they should follow; 
whether they ought to pursue or if changes are required.

Chickpea breeding in Ethiopia was started in the 1950 (Gemechu et al., 2011). Since then, a number of locally collected and newly introduced germplasm have been evaluated to develop high yielding and widely adaptable varieties. Some work has been done on the genetic progress in Ethiopian chickpea breeding. The current initiative was aimed at critically assessing the rate of genetic gain achieved in Ethiopian Kabuli chickpea breeding program at diverse agro-ecological locations so as to devise effective breeding strategy for further improvement. Therefore, the purpose of present study was to determine genetic progress in yield and yield related traits of Kabuli chickpea varieties. Though, there appear one oldest type variety release from local sources, a full-fledged breeding program for Kabuli type chickpea has mainstreamed in the early1980s.

\section{Material and Methods}

The experiment was conducted in 2017 cropping season at four locations, namely Akaki, Chefe Donsa, DZARC and Jari sub stations. The specific descriptions of the sites are given in Table 1 below. The experiment consisted of fourteen Kabuli chickpea varieties released since 1974 (Table 2). The experiment was planted in a Randomized Complete Block Design (RCBD) with three replications. The experimental plot size of 4 rows each $4 \mathrm{~m}$ long and $1.2 \mathrm{~m}$ wide $\left(4.8 \mathrm{~m}^{2}\right)$ with spacing of $30 \mathrm{~cm}$ between rows, $10 \mathrm{~cm}$ between plants and $1 \mathrm{~m}$ between blocks was used. Two hundred seeds were planted to each row. Field management and protection practices were applied based on research recommendation at each location. Data were recorded on: days to flowering, days to maturity, plant height, number of pods per plant, number of seed per pod, hundred seed weight and grain yield.

Table 1. Descriptions of the study sites

\begin{tabular}{|l|l|l|l|l|l|l|l|l|}
\hline $\begin{array}{l}\text { Experimental } \\
\text { stations }\end{array}$ & $\begin{array}{l}\text { Distance } \\
\text { from } \\
\text { Addis } \\
\text { Ababa } \\
(\mathrm{km})\end{array}$ & Longitude(E) & Latitude(N) & $\begin{array}{l}\text { Altitude } \\
(\text { masl })\end{array}$ & $\begin{array}{l}\text { Soil } \\
\text { Type }\end{array}$ & $\begin{array}{l}\text { Annual } \\
\text { Average } \\
\text { rainfall } \\
(\mathrm{mm})\end{array}$ & $\begin{array}{l}\text { Mean } \\
\text { Min. } \\
\text { Tem. } \\
\left({ }^{\circ} \mathrm{c}\right)\end{array}$ & $\begin{array}{l}\text { Mean } \\
\text { Max. } \\
\text { Temp. } \\
\left({ }^{\circ} \mathrm{c}\right)\end{array}$ \\
\hline Akaki & 20 & $38^{\circ} 47^{\prime}$ & $08^{\circ} 52^{\prime}$ & 2200 & Black & 1025 & 7.0 & 26.5 \\
\hline Chefe Donsa & 84 & $38^{\circ} 37^{\prime}$ & $08^{\circ} 58^{\prime}$ & 2450 & Black & 909 & 7.0 & 26 \\
\hline DZARC & 47 & $38^{\circ} 58^{\prime}$ & $08^{\circ} 44^{\prime}$ & 1900 & Black & 851 & $8.9^{\circ} \mathrm{c}$ & 28.3 \\
\hline Jari & 449 & $39038^{c e}$ & $1^{\circ} 21^{\prime}$ & 1680 & Vertisol & NA & NA & NA \\
\hline
\end{tabular}

Source: Debre zeit Agricultural Research Center (Abera and Kebede, 2014) and Sirinka Agricultural Research Centers for altitude, rain fall and soil type; Wikipedia for global position. NA= not available

Table 2. Kabuli chickpea varieties released in Ethiopia from 1974 to 2016

\begin{tabular}{|l|l|l|l|l|l|}
\hline No & Variety & \multicolumn{1}{|c|}{ Pedigree } & Source & $\begin{array}{l}\text { Year of } \\
\text { release } \\
\text { d }\end{array}$ & $\begin{array}{l}\text { Released } \\
\text { research } \\
\text { center }\end{array}$ \\
\hline 1 & DZ-10-4 & ----- & Ethiopia & 1974 & DZARC \\
\hline 2 & Arerti & X87TH186/ICC14198XFLIP 82-150C & ICARDA & 1999 & DZARC \\
\hline 3 & Shasho & ICCC33X(L144XE1004Y(M) & ICRISAT & 1999 & DZARC \\
\hline 4 & Chefe & (ICCV2XSURUTATO77)ICC-7344 & ICRISAT & 2004 & DZARC \\
\hline 5 & Habru & X85TH230/ILC3395XFLIP 83-13C) & ICARDA & 2004 & DZARC \\
\hline 6 & Ejerie & X94TH71/FLIP87-59CX4C-15 & ICARDA & 2005 & DZARC \\
\hline 7 & Teji & X94TH75/FLIP87-58CX4C-15 & ICARDA & 2005 & DZARC \\
\hline 8 & Yelibie & ICC-14808 & ICRISAT & 2006 & SARC \\
\hline 9 & Acos dubie & ICC 13XANNIGERI & Mexico & 2009 & DZARC \\
\hline 10 & Kasech & FLIP 95-31C & ICRISAT & 2011 & SARC \\
\hline 11 & Akuri & ICC-03402 & ICRISAT & 2011 & SARC \\
\hline 12 & Kobo & ICCV-01308 & ICRISAT & 2012 & SARC \\
\hline 13 & Hora & X2000TH50/FLIP 98-52C X FLIP 98-12C & ICARDA & 2016 & DZARC \\
\hline 14 & Dhera & X98TH30/FLIP-93-55C X S-96231 & ICARDA & 2016 & DZARC \\
\hline
\end{tabular}

\subsection{Statistical Analysis}

All measured parameters were subjected to analysis of variance (ANOVA) using PROC GLM of SAS software version 9.0 to assess the difference among the tested varieties. The homogeneity of error mean squares between the four locations was tested by Bartlett's chi-square test and combined analyses of variance were performed for the traits whose error mean squares were homogenous. Mean separation was carried out using Duncan's Multiple Range Test (DMRT). The breeding effect was estimated as a genetic gain for grain yield and associated traits; by regressing the mean of each character of each variety against the year of release of the variety using PROC REG procedure. The coefficient of linear regression gives the estimate of genetic gain in $\mathrm{kg} \mathrm{ha}^{-1} \mathrm{yr}^{-1}$ or in $\%$ per year 
(Evans and Fisher, 1999). For this study, the year of release was expressed as the number of years since 1974 for the varieties; the year when the first chickpea variety was released. Calculation was done as follows.

Annual rate of gain $(\mathrm{b})=\mathrm{CovXY} / \mathrm{VarX}$

Where: $\quad \operatorname{Cov}=$ Covariance, Var $=$ Variance, $\mathrm{X}=$ the year of variety release and $\mathrm{Y}=$ the mean value of each character for each variety

The relative annual gain achieved over the last 42 years (1974-2016) was determined as a ratio of genetic gain to the corresponding mean value of oldest variety and expressed as percentage. Stepwise regression analysis was carried out on the varietal mean to determine those traits that contributed much for yield variation among varieties. To compute Pearson's product moment correlation coefficients among all characters using means of each variety, PROC CORR in SAS was used.

\section{RESULT AND DISCUSSION}

\subsection{Analysis of Variance}

The analysis of variance for individual locations revealed highly significant $(\mathrm{P}<0.01)$ differences among tested varieties for all traits (Table 3). Combined analysis of variance across the four locations also revealed highly significant effects of location, variety and variety $\mathrm{x}$ location interaction for all traits studied (Table 4). Similarly, Fikre et al. (2012); Tamene et al. (2015); Mekuria et al. (2018) in ground nut, faba bean and durum wheat varieties reported significant $(\mathrm{p} \leq 0.01)$ interaction effects for grain yield, though, this is in contrast to the finding of Hailu et al. (2009); wondimu et al. (2011) and Ersullo et al. (2016) in soybean, barley and linseed respectively.

Table 3.Mean squares from separate analysis of variance for grain yield and other traits of Kabuli chickpea at four locations

\begin{tabular}{|c|c|c|c|c|c|c|c|c|}
\hline \multirow[t]{2}{*}{ traits } & \multicolumn{7}{|c|}{ Mean squares (MS) at each location } & \\
\hline & Debre Zeit & & $\begin{array}{l}\text { Chefe } \\
\text { Donsa }\end{array}$ & & Akaki & & Jari & \\
\hline & Variety & Error & Variety & Error & Variety & Error & Variety & error \\
\hline DF & $47.47^{* *}$ & 2.06 & $54.57^{* *}$ & 1.35 & $32.88^{* *}$ & 1.88 & $34.55^{* *}$ & 1.99 \\
\hline DM & $11.47^{* *}$ & 1.81 & $80.70^{* *}$ & 2.30 & $8.32^{* *}$ & 2.31 & $17.72^{* *}$ & 2.30 \\
\hline PTH & $74.44^{* *}$ & 5.61 & $91.39^{* *}$ & 4.73 & $31.28^{* *}$ & 5.60 & $77.19^{* *}$ & 7.53 \\
\hline $\begin{array}{l}\text { NPP } \\
\text { P }\end{array}$ & $110.79^{* *}$ & 22.27 & $544.83^{* *}$ & 71.91 & $225.04^{* *}$ & 16.99 & $419.03^{* *}$ & 103.98 \\
\hline $\begin{array}{l}\text { NSP } \\
\mathbf{P}\end{array}$ & $0.036^{* *}$ & 0.007 & $0.029^{* *}$ & 0.009 & $0.064^{* *}$ & 0.006 & $0.12^{* *}$ & 0.007 \\
\hline HSW & $339.53^{* *}$ & 1.49 & $236.37^{* *}$ & 1.52 & $411.62^{* *}$ & 2.86 & $481.06^{* *}$ & 3.35 \\
\hline GY & 1938657.3* & $\begin{array}{l}165439 . \\
3\end{array}$ & $\underset{* *}{2926413.15}$ & $\begin{array}{l}215338 . \\
3\end{array}$ & $\begin{array}{l}993572.9 \\
6^{* *}\end{array}$ & $\begin{array}{l}242119 . \\
3\end{array}$ & ${\underset{* *}{* *}}_{3364198.35}$ & $\begin{array}{l}291574.1 \\
3\end{array}$ \\
\hline
\end{tabular}

**, $*$, ns $=$ Significant at $\mathrm{P} \leq 0.01$, significant at $\mathrm{P} \leq 0.05$ and non-significant respectively $€=\mathrm{DF}=$ days to flowering, $\mathrm{DM}=$ days to physiological maturity, $\mathrm{PTH}=$ plant height $(\mathrm{cm}), \mathrm{NPPP}=$ number of pods per plant, $\mathrm{NSPP}=$ number of seeds per pod, HSW= hundred seed weight $(\mathrm{g})$ and $\mathrm{GY}=$ grain yield $\left(\mathrm{Kg} \mathrm{ha}^{-1}\right)$.

\subsection{Grain Yield Potential}

The grain yield performance of all Kabuli chickpea varieties averaged over locations was $3264.48 \mathrm{~kg} \mathrm{ha}^{-1}$, which ranged from $1541.3 \mathrm{~kg} \mathrm{ha}^{-1}$ for the variety Acos dubie to $4074.2 \mathrm{~kg} \mathrm{ha}^{-1}$ for the variety Arerti (Table 5). The variety Acos dubie, showed lower grain yield than all varieties represented in the current study. The variety Arerti, which was released in 1999, was the highest yielding variety among the tested varieties. The recently released variety Hora was the second best yielder among the varieties next to Arerti (Table 5). The poor relative yield of Acos dubie in this study may be due to its super bold seed size (Table 6), which presumably has compromised for the gain in yield. 
Table 4. Mean squares from combined analysis of variance for yield and other traits of Kabuli chickpea evaluated over four locations in 2017 Cropping Season

\begin{tabular}{|c|c|c|c|c|c|c|c|}
\hline Trait $^{€}$ & Location(3) $¥$ & Variety(13) & $\begin{array}{l}\text { Location } \\
\text { Variety(39) }\end{array}$ & Error(104) & Mean & $\mathrm{CV}$ & $\mathbf{R}^{2}$ \\
\hline DF & $1159.75 * *$ & $130.38 * *$ & $13.07 * *$ & 1.80 & 56.61 & 2.37 & 0.97 \\
\hline DM & $4891.33 * *$ & $57.91 * *$ & $20.10 * *$ & 2.18 & 129.52 & 1.14 & 0.99 \\
\hline PTH & $1639.68 * *$ & $181.22 * *$ & $31.021 * *$ & 5.87 & 49.70 & 4.87 & 0.93 \\
\hline NPPP & $6442.27 * *$ & $918.92 * *$ & $126.93 * *$ & 53.79 & 41.47 & 17.68 & 0.87 \\
\hline NSPP & $0.039 * *$ & $0.177 * *$ & $0.033 * *$ & 0.0078 & 1.198 & 7.39 & 0.81 \\
\hline HSW & $1386.14 * *$ & $1423.06 * *$ & $15.17340 * *$ & 2.30 & 32.86 & 4.62 & 0.99 \\
\hline GY & $66187429.2 * *$ & $5913044.3 * *$ & $1115687.6 * *$ & 223897.7 & 3264.48 & 14.49 & 0.93 \\
\hline
\end{tabular}

$¥=$ Numbers in parenthesis represent degrees of freedom

$€=$ Abbreviations of traits, refer to Table $3, \mathrm{CV}=$ Coefficient of variation, $\mathrm{R}^{2}=$ Proportion of total variation explained by the model (i.e., by location, replications within location, variety, and variety $\mathrm{x}$ location interaction effects), **, *, ns $=$ Significant at $\mathrm{P} \leq 0.01$, significant at $\mathrm{P} \leq 0.05$ and no significant respectively

Table 5. Mean grain yield (Kg/ha) of Kabuli type chickpea varieties at four locations

\begin{tabular}{|c|c|c|c|c|c|}
\hline \multirow[b]{2}{*}{ Variety } & \multicolumn{4}{|c|}{ Location } & \multirow[b]{2}{*}{ Mean } \\
\hline & Akaki & Debre Zeit & Chefe Donsa & Jari & \\
\hline DZ-10-4 & $2948.7^{\mathrm{cd}}$ & $1268.7^{\mathrm{g}}$ & $642.0^{\mathrm{f}}$ & $3821.0^{\mathrm{e}}$ & $2153.4^{\mathrm{g}}$ \\
\hline Arerti & $4701.7^{\mathrm{a}}$ & $2305.7^{\mathrm{def}}$ & $3057.3^{\mathrm{bc}}$ & $6232.0^{\mathrm{a}}$ & $4074.2^{\mathrm{a}}$ \\
\hline Shasho & $3390.0^{\mathrm{bc}}$ & $2502.3^{\mathrm{cd}}$ & $2173.7^{\mathrm{cd}}$ & $5483.7^{\mathrm{abcd}}$ & $3387.4^{\text {cde }}$ \\
\hline Chefe & $4205.7^{\mathrm{ab}}$ & $2600.3^{\mathrm{cd}}$ & $1767.0^{\text {de }}$ & $5169.7^{\mathrm{bcd}}$ & $3435.7^{\text {cde }}$ \\
\hline Habru & $3289.7^{\mathrm{bcd}}$ & $2674.7^{\mathrm{cd}}$ & $2727.0^{\mathrm{bc}}$ & $5858.3^{a b}$ & $3637.4^{\text {bcd }}$ \\
\hline Ejere & $3613.7^{\mathrm{bc}}$ & $3174.3^{\mathrm{abc}}$ & $2886.0^{\mathrm{bc}}$ & $4823.7^{\mathrm{cd}}$ & $3624.4^{\mathrm{bcd}}$ \\
\hline Teji & $3494.0^{\mathrm{bc}}$ & $3020.0^{\mathrm{bcd}}$ & $1263.7^{\mathrm{ef}}$ & $5279.0^{\mathrm{a}-\mathrm{d}}$ & $3264.2^{\mathrm{de}}$ \\
\hline Yelibie & $3207.7^{\mathrm{cd}}$ & $1603.3^{\mathrm{fg}}$ & $3012.3^{\mathrm{bc}}$ & $4801.7^{\text {cde }}$ & $3156.3^{\text {ef }}$ \\
\hline Acos dubie & $2378.0^{\mathrm{d}}$ & $1042.3^{g}$ & $621.0^{\mathrm{f}}$ & $2123.7^{f}$ & $1541.3^{\mathrm{h}}$ \\
\hline Kasech & $3541.3^{\mathrm{bc}}$ & $2384.7^{\mathrm{de}}$ & $3190.7^{b}$ & $6076.3^{\mathrm{ab}}$ & $3798.3^{\mathrm{abc}}$ \\
\hline Akuri & $3214.3^{\mathrm{cd}}$ & $1674.3^{\mathrm{efg}}$ & $1619.7^{\mathrm{de}}$ & $4627.7^{\text {cde }}$ & $2784.0^{f}$ \\
\hline Kobo & $2782.3^{\mathrm{cd}}$ & $3791.7^{\mathrm{a}}$ & $2449.7^{\mathrm{bcd}}$ & $5619.7^{\mathrm{abc}}$ & $3660.8^{a-d}$ \\
\hline Hora & $2995.7^{\mathrm{cd}}$ & $3432.3^{\mathrm{ab}}$ & $3994.7^{\mathrm{a}}$ & $5580.7^{\mathrm{abc}}$ & $4000.8^{a b}$ \\
\hline Dhera & $3531.7^{\mathrm{bc}}$ & $2396.0^{\text {de }}$ & $2291.7^{\mathrm{cd}}$ & $4519.3^{\mathrm{de}}$ & $3184.7^{\text {ef }}$ \\
\hline $\mathbf{C V}$ & 14.57 & 16.81 & 20.50 & 10.80 & 14.49 \\
\hline Mean & 3378.17 & 2419.33 & 2264.02 & 5001.17 & 3264.48 \\
\hline $\mathbf{R}^{2}$ & 0.72 & 0.86 & 0.88 & 0.85 & 0.93 \\
\hline
\end{tabular}

Means followed by the same letter with in a column are not significantly different from each other at $\mathrm{P} \leq 0.05$.

Table 6. Mean Values of Different Traits from Combined Analysis of Variance for Kabuli Type Chickpea Varieties in the Yield Potential Trials at Four Locations.

\begin{tabular}{|c|c|c|c|c|c|c|}
\hline \multirow[b]{2}{*}{ Variety } & \multicolumn{4}{|c|}{ Trait } & \multirow[b]{2}{*}{ NSPP } & \multirow[b]{2}{*}{ HSW } \\
\hline & DF & DM & PTH & NPPP & & \\
\hline DZ-10-4 & $57.83^{\mathrm{c}}$ & $128.17^{\mathrm{e}}$ & $44.70^{\mathrm{g}}$ & $51.80^{\mathrm{b}}$ & $1.54^{\mathrm{a}}$ & $12.91^{\mathrm{h}}$ \\
\hline Arerti & $59.17^{b}$ & $129.50^{\mathrm{d}}$ & $48.23^{\mathrm{ef}}$ & $50.85^{\mathrm{b}}$ & $1.09^{\mathrm{g}}$ & $27.25^{\mathrm{g}}$ \\
\hline Shasho & $59.58^{b}$ & $130.42^{\mathrm{cd}}$ & $49.47^{\mathrm{c}-\mathrm{f}}$ & $58.05^{\mathrm{a}}$ & $1.15^{\mathrm{efg}}$ & $29.68^{f}$ \\
\hline Chefe & $55.58^{d}$ & $130.58^{\mathrm{cd}}$ & $50.83^{\text {bcd }}$ & $48.02^{\mathrm{bc}}$ & $1.20^{\text {cde }}$ & $31.57^{\mathrm{de}}$ \\
\hline Habru & $54.25^{\mathrm{e}}$ & $127.58^{\mathrm{e}}$ & $50.38^{\text {cde }}$ & $39.783^{\mathrm{de}}$ & $1.22^{\text {bcde }}$ & $31.21^{\mathrm{e}}$ \\
\hline Ejere & $53.92^{\mathrm{e}}$ & $128.17^{\mathrm{e}}$ & $50.35^{\text {cde }}$ & $38.650^{\mathrm{de}}$ & $1.29^{\mathrm{b}}$ & $32.83^{\text {bcd }}$ \\
\hline Teji & $55.08^{\mathrm{de}}$ & $131.50^{\mathrm{bc}}$ & $47.42^{\mathrm{f}}$ & $40.750^{\mathrm{de}}$ & $1.23^{\mathrm{bcd}}$ & $33.74^{\mathrm{b}}$ \\
\hline Yelibie & $54.00^{\mathrm{e}}$ & $127.50^{\mathrm{e}}$ & $49.12^{\text {def }}$ & $37.367^{\mathrm{de}}$ & $1.26^{\mathrm{bc}}$ & $32.08^{\text {cde }}$ \\
\hline Acosdubie & $54.25^{\mathrm{e}}$ & $133.50^{\mathrm{a}}$ & $50.03^{\text {cde }}$ & $21.933^{f}$ & $1.08^{\mathrm{g}}$ & $65.89^{a}$ \\
\hline Kasech & $54.42^{\mathrm{e}}$ & $127.83^{\mathrm{e}}$ & $52.73^{b}$ & $42.72^{\mathrm{cd}}$ & $1.18^{\mathrm{def}}$ & $31.02^{\mathrm{e}}$ \\
\hline Akuri & $52.08^{\mathrm{f}}$ & $125.42^{\mathrm{f}}$ & $41.55^{\mathrm{h}}$ & $34.967^{\mathrm{e}}$ & $1.25^{\mathrm{bcd}}$ & $32.39^{\text {cde }}$ \\
\hline Kobo & $59.42^{\mathrm{b}}$ & $130.67^{\mathrm{cd}}$ & $50.82^{\text {bcd }}$ & $36.967^{\mathrm{de}}$ & $1.10^{\mathrm{fg}}$ & $33.33^{\mathrm{bc}}$ \\
\hline Hora & $58.67^{\mathrm{bc}}$ & $129.92^{\mathrm{d}}$ & $51.45^{\mathrm{bc}}$ & $38.917^{\mathrm{de}}$ & $1.11^{\mathrm{fg}}$ & $32.26^{\text {cde }}$ \\
\hline Dhera & $64.25^{\mathrm{a}}$ & $132.42^{\mathrm{ab}}$ & $58.72^{\mathrm{a}}$ & $39.867^{\mathrm{de}}$ & $1.08 \mathrm{~g}$ & $33.84^{\mathrm{b}}$ \\
\hline $\mathrm{Cv}$ & 2.37 & 1.14 & 4.87 & 17.68 & 7.39 & 4.62 \\
\hline Mean & 56.61 & 129.51 & 49.70 & 41.47 & 1.198 & 32.86 \\
\hline $\mathbf{R}^{2}$ & 0.97 & 0.99 & 0.93 & 0.87 & 0.81 & 0.99 \\
\hline
\end{tabular}




\subsection{Genetic Progress for Yield and other Traits}

\subsubsection{Grain yield}

The mean grain yield of varieties released in 1970s, 1990s and 2000s were 2153.4, 3730.8 and $3280.7 \mathrm{~kg} \mathrm{ha}^{-1}$ (Table 8), respectively. These result indicated an increase of $1577.4(73.25 \%)$ and $1127.3 \mathrm{~kg} \mathrm{ha}^{-1}(52.35 \%)$ over the first released variety (Table 8), respectively. The average grain yield of the varieties released in 2000s was greater than that of the first released variety in 1974 (DZ-10-4), but less than the mean yield of the varieties released in $1990 \mathrm{~s}$ by $450.1 \mathrm{~kg} \mathrm{ha}^{-1}(12.06 \%)$ Table 8$)$. In this context we learnt the breeding program has made strategic shift in its objective from merely yield deriver to some other market traits deriver like seed size. For example, releasing Acos Dubie 2009, we can see a big compromise on the count of yield progress measurement in time.

Table 7. Genetic Progress Trend in Grain Yield and Hundred Seed Weight (HSW) for Kabuli Type Chickpea Varieties Released from 1999 to 2016 over the Older Variety (DZ-10-4) Released in 1974

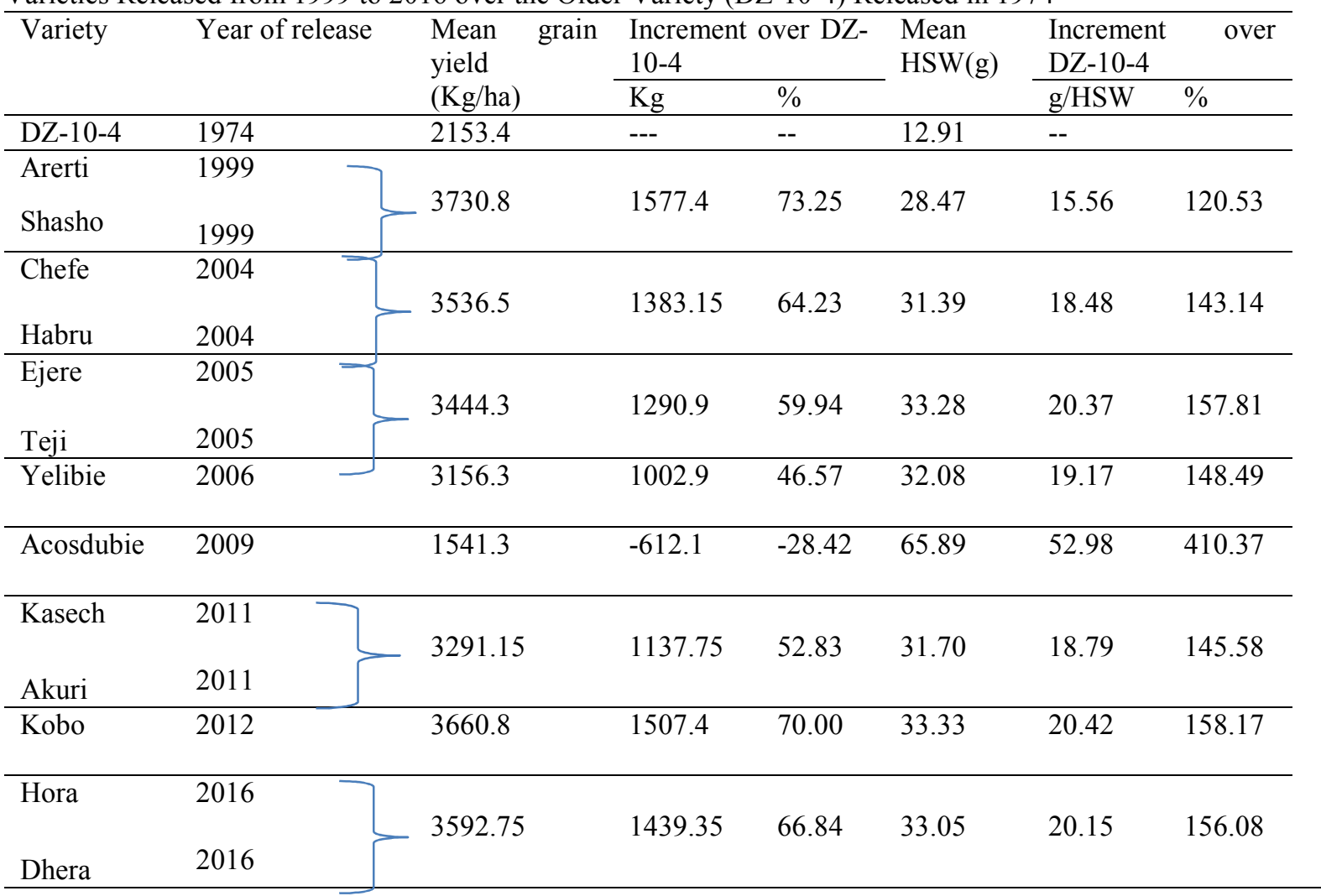

Table 8. Genetic Progress Trend in Grain Yield and Hundred Seed Weight (HSW) For Kabuli Type Chickpea Varieties Released in 1990s and 2000s over the Older Variety DZ-10-4 Released in 1974

\begin{tabular}{|c|c|c|c|c|c|c|c|c|}
\hline \multirow[t]{2}{*}{ Variety } & \multirow[t]{2}{*}{$\begin{array}{l}\text { Year } \\
\text { release }\end{array}$} & \multirow[t]{2}{*}{ of } & \multirow[t]{2}{*}{$\begin{array}{l}\text { Mean } \\
\text { yield }\end{array}$} & $\begin{array}{l}\text { Increment } \\
\text { DZ-10-4 }\end{array}$ & \multirow[t]{2}{*}{ over } & \multirow[t]{2}{*}{$\begin{array}{l}\text { Mean HSW } \\
\text { (g) }\end{array}$} & \multirow{2}{*}{$\begin{array}{l}\text { Increment } \\
10-4 \\
\text { ghsw }^{-1}\end{array}$} & \multirow{2}{*}{$\begin{array}{l}\text { over DZ- } \\
\%\end{array}$} \\
\hline & & & & $\mathrm{Kg}$ & & & & \\
\hline DZ-10-4 & 1974 & & 2153.4 & - & - & 12.91 & - & - \\
\hline $\begin{array}{l}\text { Arerti } \\
\text { Shasho }\end{array}$ & $1990 \mathrm{~s}$ & & 3730.8 & 1577.4 & 73.25 & 28.47 & 15.56 & 120.53 \\
\hline $\begin{array}{l}\text { Chefe } \\
\text { Habru } \\
\text { Ejere } \\
\text { Teji } \\
\text { Yelibie } \\
\text { Acosdubie } \\
\text { Kasech } \\
\text { Akuri } \\
\text { Kobo } \\
\text { Hora } \\
\text { Dhera }\end{array}$ & $2000 \mathrm{~s}$ & - & 3280.7 & 1127.3 & 52.35 & 35.39 & 22.48 & 174.13 \\
\hline
\end{tabular}

Varieties derived from introductions yielded an average of $3349.96 \mathrm{~kg} / \mathrm{ha}$, and surpassed the varieties 
developed from local collections by $1196.56 \mathrm{~kg} \mathrm{ha}^{-1}$ (55.57\%) (Table 9). Similarly, Sanchez-Garcia et al. (2013) revealed that the introduction of improved bread wheat varieties in Spain during the $20^{\text {th }}$ century enhanced breadmaking quality. The results of the present study indicated that the Kabuli chickpea improvement program that employed selection from introductions as major breeding methods was successful in improving grain yield, though the rate of gain is negatively accelerated in time. Similarly, Kebere. (2006); Mekuria et al. (2018); have indicated that introduced materials contributed a lot to the improvement of the genetic yield potential of durum wheat and haricot bean varieties in Ethiopia, respectively.

Table 9. Average Increments in Grain Yield and Hundred Seed Weight (HSW) for Kabuli Type Chickpea Varieties Derived from Introduction over Variety Derived from Local Collection

\begin{tabular}{|c|c|c|c|c|c|c|}
\hline \multirow[t]{2}{*}{ Variety } & \multirow[t]{2}{*}{$\begin{array}{l}\text { Grain } \\
(\mathrm{kg} / \mathrm{ha})\end{array}$} & \multicolumn{2}{|c|}{$\begin{array}{l}\text { Grain yield increment over } \\
\text { local collection }\end{array}$} & \multirow[t]{2}{*}{$\begin{array}{l}\text { Mean } \\
\text { HSW (g) }\end{array}$} & \multicolumn{2}{|c|}{$\begin{array}{l}\text { HSW increment over local } \\
\text { collection }\end{array}$} \\
\hline & & $\mathrm{Kgha}^{-1}$ & $\%$ & & ghsw $^{-1}$ & $\%$ \\
\hline $\begin{array}{l}\text { Local collection } \\
\text { derived }\end{array}$ & 2153.4 & --- & -- & 12.91 & - & - \\
\hline $\begin{array}{l}\text { Introduction } \\
\text { derived }\end{array}$ & 3349.96 & 1196.56 & 55.57 & 34.39 & 21.38 & 165.61 \\
\hline
\end{tabular}

The genetic gain analysis revealed an average rate of increase of $22.35 \mathrm{~kg} \mathrm{ha}^{-1} \mathrm{yr}^{-1}$ in yield potential over the last 42 years since 1974 (Figure 1) in Kabuli chickpea, which is not significantly different from zero ( $\mathrm{P} \leq 0.05)$. The average relative annual gain in grain yield was $1.04 \%$ per year or about $43.68 \%$ for the whole period (Table 11$)$. This evidently showed that chickpea breeders have made efforts over the last 42 years to improve the yield of Kabuli type chickpea in Ethiopia, however, hardly in leap progressive. Similarly, Alisson et al. (2010) reported in the period ranging from 1997 to 2007, the estimate of genetic progression was null. Likewise, Ersullo et al. (2016) reported in the first era (since 1984), the relative rate of genetic gains in grain yields of linseed was $4.15 \mathrm{~kg} \mathrm{ha}^{-1} \mathrm{yr}^{-}$ ${ }^{1}$ of the modern cultivars over that of the older ones was non-significant. Similarly, Wondimu et al. (2013) in grain yield of malt barley reported that slope of regression since 1973 was not significantly different from zero at each location as well as across locations. In contrary, Follmann et al. (2017) reported annual genetic progress of sunflower during the period of 10 years (2005-2014) was $132.46 \mathrm{kgha}^{-1} \mathrm{year}^{-1}$ for grain yield was significant.

The genetic progresses made in grain yield of Kabuli chickpea breeding (1.04\%) in this study is much lower than the progresses made in grain yields from breeding of other crops like haricot bean $\left(3.24 \% \mathrm{ha}^{-1}\right.$ year $\left.^{-1}\right)(\mathrm{Kebere}$ et al., 2006) , barley (1.34\% ha $\left.\mathrm{hear}^{-1}\right)$ (Wondimu et al., 2011), groundnut $\left(1.89 \% \mathrm{ha}^{-1}\right.$ year $\left.^{-1}\right)$ (Fikre et al., 2012)and linseed (4.33, 9.78 and 10.45\% ha $^{-1}$ year $^{-1}$ since 1984, 1992 and 1997 respectively) (Ersullo et al., 2016) but little higher than that of malt barley $\left(0.88 \% \mathrm{ha}^{-1}\right.$ year $\left.^{-1}\right)$ (Wondimu et al.,2013) ,faba bean $\left(0.26 \% \mathrm{ha}^{-1} \mathrm{year}^{-1}\right)$ (Tamene et al., 2015), more or less during the same period in Ethiopia and in other countries, $0.58 \%$ ha $^{-1}$ year $^{-1}$ from breeding soybean in Northeast China (Jin et al., 2010), $0.45 \% \mathrm{ha}^{-1}$ year $^{-1}$ from breeding soybean in Canada (Morrison, et al. 2000) and $0.39 \% \mathrm{ha}^{-1}$ year $^{-1}$ from hundred years of barley breeding in England (Riggs, et al., 1981).

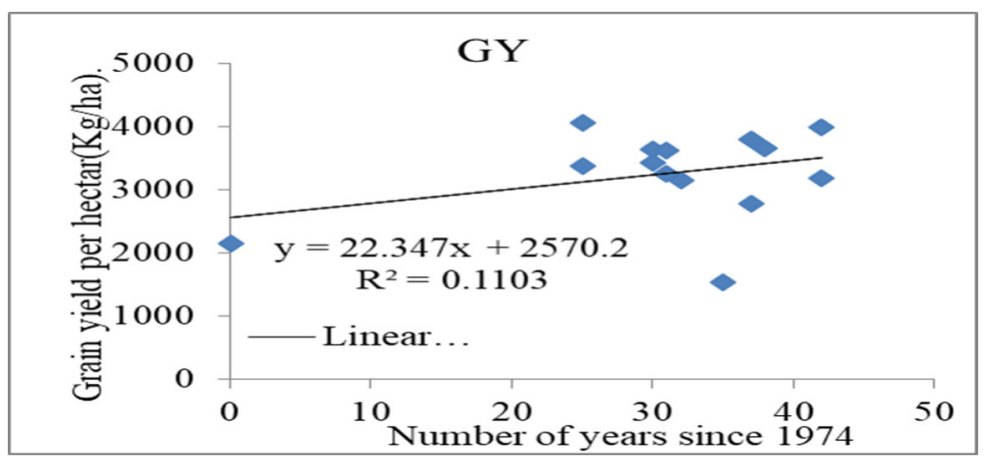

Figure 1. Relationship between year of Kabuli chickpea variety releases and grain yield across location in

\subsubsection{Hundred Seed Weight}

Ethiopia

Mean hundred seed weight ranged from 12.91g (DZ-10-4) to $65.89 \mathrm{~g}$ (Acos duie) with across location average of $32.86 \mathrm{~g}$ (Table 6). Acos dubie, which was released in 2009, had significantly higher seed size (hundred seed weight) than all of the varieties in this study. It surpassed the first older variety (DZ-10-4) by $52.98 \mathrm{~g}(410.37 \%)$ in hundred seed weight. The mean hundred seed weight of varieties that released in 1974, 1999, 2004, 2005, 2006 , 2009,2011,2012 and 2016 were 12.91, 28.47, 31.39, 33.28, 32.08, 65.89, 31.7, 33.33 and 33.05g, respectively (Table 7). This indicated an increase of $15.56 \mathrm{~g}(120.53 \%), 18.48 \mathrm{~g}(143.14 \%), 20.37 \mathrm{~g}(157.81 \%), 19.17 \mathrm{~g}$ (148.49\%) and 52.98g (410.37\%), 18.79g (145.58\%), 20.42(158.17\%), and 20.15g (156.08\%) in hundred seed weight, respectively, over the older varieties (Table 7). 
The regression of hundred seed weight against the years of release showed annual rate of genetic gain of 0.56

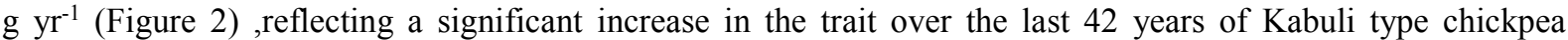
improvement in Ethiopia with a relative annual genetic gain of 4.37\% (Table 11). Generally, this experiment clearly revealed that improved genetic progress was obtained from breeding kabuli chickpea in Ethiopia for seed size than it was for grain yield. Similarly, Wych and Rasmusson (1983) in malting barley; Cox et al. (1988) in hard red winter wheat; Amsal (1994) in durum wheat, Ortiz et al. (2002) in two-row Nordic spring barley, Tamene et al .(2015) in faba bean and Ersullo et al. (2016) in linseed found that thousand seed weight of modern varieties were heavier than the older ones. Similar results with more dramatic increments in seed size than in grain yield, was also reported from chickpea breeding in Ethiopia (Gemechu et al., 2011).

Like to the grain yield, varieties derived from introductions gave higher hundred seed weight, which was $34.39 \mathrm{~g}$ on average, and exceeded the mean of the varieties developed through local collection by $21.38 \mathrm{~g}(165.61 \%)$ (Table 9). This result is contrary to the finding of Tamene et al. (2015) in faba bean.

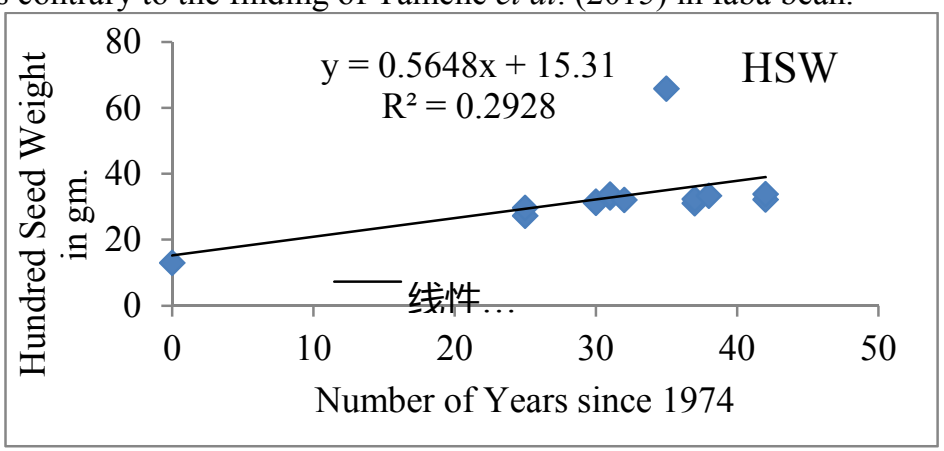

Figure 2. Relationship between year of variety release and hundred seed weight across

Table 10. Estimation of mean values and regression coefficient (b) of various agronomic traits from linear regression of the mean value of each character for each variety against the year of release

\begin{tabular}{lllll}
\hline Character & Mean & $\mathrm{R}^{2}$ & $\mathrm{~b}$ & Intercept \\
\hline Days to flowering & 56.61 & 0.0002 & 0.0045 & 56.47 \\
Days to maturity & 129.52 & 0.0419 & 0.0431 & 128.17 \\
Plant height & 49.7 & 0.2429 & 0.1836 & 43.997 \\
Number of pod per plant & 41.47 & 0.3204 & $-0.4748^{*}$ & 56.23 \\
Number of seed per pod & 1.20 & 0.6046 & $-0.0091^{* *}$ & 1.48 \\
Hundred seed weight & 32.86 & 0.2928 & $0.5648^{*}$ & 15.31 \\
Grain yield & 3264.48 & 0.1103 & 22.347 & 2570.2 \\
\hline
\end{tabular}

Table 11. Annual Relative Genetic Gain and Correlation Coefficients for Grain Yield and Different Attributes Of Kabuli Type Chickpea Varieties

\begin{tabular}{|c|c|c|c|c|}
\hline \multirow[t]{2}{*}{ Characters } & \multirow{2}{*}{$\begin{array}{l}\text { Mean of the older } \\
\text { variety } \\
\text { (DZ-10-4) }\end{array}$} & \multirow[t]{2}{*}{$\begin{array}{l}\text { Relative genetic gain }(\% \text { year } \\
\left.{ }^{1}\right)\end{array}$} & \multicolumn{2}{|c|}{$\begin{array}{l}\text { Correlation } \\
\text { coefficient(r) }\end{array}$} \\
\hline & & & GY/ha & HSW \\
\hline Days to flowering & 57.83 & 0.01 & 0.21 & -0.23 \\
\hline Days to maturity & 128.17 & 0.03 & -0.22 & $0.54 *$ \\
\hline Plant height & 44.7 & 0.41 & 0.31 & 0.22 \\
\hline $\begin{array}{l}\text { Number of pod per } \\
\text { plant }\end{array}$ & 51.80 & -0.92 & 0.40 & $-0.78 * *$ \\
\hline Number of seed per pod & 1.54 & -0.59 & -0.33 & $-0.59 *$ \\
\hline Hundred seed weight & 12.91 & 4.37 & -0.42 & -- \\
\hline Grain yield & 2153.4 & 1.04 & -- & -0.42 \\
\hline
\end{tabular}

\subsubsection{Plant height}

Among the recently released varieties, the tallest plant height was observed in variety 'Dhera' $(58.72 \mathrm{~cm})$ that was of course released for mechanized harvesting purpose, while 'Akuri', which was released in $2011(41.55 \mathrm{~cm})$ had the shortest plant height (Table 6). The regression of plant height against the years of release showed annual rate of genetic gain of $0.1836 \mathrm{~cm} \mathrm{ha}^{-1}$ year-1 $^{-1}$ Table 10) with a relative annual genetic gain of $0.41 \%$, though it was not significantly different from zero (Table 11). Similarly, Yifru and Hailu (2005) reported that plant height was taller for the modern Tef varieties than the older ones, even though the relative genetic gain over the 35 years period of breeding was low $(0.42) \mathrm{cm}$ per year, and was not significantly $(\mathrm{P}<0.05)$ different from zero. In contrary to this study, Nurberdy et al. (2015) and Mekuria et al. (2018) observed a significant reduction in plant height in winter wheat in turkey and durum wheat in Ethiopia, respectively. Mihret et al. (2015) reported a negatively nonsignificant annual rate of gain in plant height against year of release with the average annual genetic gain and 
annual relative percentage gain of $-0.39 \mathrm{~cm}$ year $^{-1}$ and $-0.16 \%$ per year.

\subsubsection{Number of Pods per plant and seeds per pod}

Mean number of pods per plant and number of seeds per pod average across location were 41.47 and 1.198 respectively (Table 6). From this study, the number of pods per plant and number of seeds per pod followed a decreasing trend over 42 years of Kabuli chickpea improvement program as seen from the significant and highly significant negative linear regression coefficients(Table 10) with relative annual gains of -0.92 and -0.59 , respectively(Table 11). In contrast, kebere et al. (2006) reported there was an increasing tendency in the number of pods plant ${ }^{-1}$.

\subsubsection{Days to flowering and maturity}

The recently released variety, Dhera was the latest to reach flowering and maturity (Table 6), while 'Akuri' (released in 2011) was the earliest (52.08 days) to flower and 125.42 days to mature (Table 6). The regression analysis of days to flowering against the year of release indicated a non- significant increase in annual genetic gain of 0.0045 days $\mathrm{yr}^{-1}$ (Table 10) with the relative genetic gain of $0.01 \%$ (Table 11 ). In contrast, Ribeiro et al. (2008); Fikre et al. (2012) reported a negative genetic gain for the number of days to $50 \%$ flowering in common bean. In addition, days to physiological maturity showed a non- significant positive increase in annual genetic gain of 0.043 days per year (Table 10), with relative genetic gain of $0.03 \%$ (Table 11). Similarly, Kebere et al. (2006); Tamene (2008), Demissewu (2010) and Mekuria et al. (2018) found a non-significant increase in days to maturity in haricot bean, faba bean, soybean and durum wheat breeding, respectively. In contrast, Wondimu et al. (2013) reported non-significant negative trends for days to flowering and maturity in food barley.

\subsection{Correlation between traits}

The correlation coefficients of grain yield and hundred seed weight with all the traits studied are presented in (Table 12). The result showed that non-significant positive association between grain yield and plant height. It is often common to see high chickpea plants with pod bearing parts raising above shade zone, means small area for pod production. Yifru and Hailu (2005); Wondimu et al. (2013); Mihret et al. (2015); also reported statistically non- significant association between grain yield and plant height in teff, malt barley and lowland sorghum, respectively. In contrast, Demissew (2010) reported a highly significant increase and significant positive correlation of plant height with grain yield in soybean. Jin et al. (2010) on soybean observed negative correlation between plant height and grain yield.

Non-significant positive correlation was observed between grain yield and the number of pods plant ${ }^{-1}$, while number of seeds pod $^{-1}$ and hundred seed weight showed negative and non-significant association with grain yield (Table 12). Kulwal and Mhase (2016) reported yield which is influenced by seed weight is the enhanced assimilation of metabolites and their transformation to yield components. Hundred seed weight showed significantly negative associations with number of pods plant ${ }^{-1}$ and number of seeds pod ${ }^{-1}$ (Table 12). According to Dewey and Lu (1959), more seeds per pod might cause a reduction of the average seed size because of competition among seeds for limited food reserves. According to Sharma and Saini (2010), days to maturity and days to flowering showed non-significant negative and positive correlations with grain yield, respectively in chickpea. On the contrary, Singh et al. (1990) in chickpea, and Hailu et al. (2009) and Demissew (2010) in soybean reported strong positive correlations of grain yield with days to flowering and days to maturity.

Table 12. Estimates of correlation coefficient among traits of Kabuli chickpea varieties

\begin{tabular}{lllllllll}
\hline & YOR & DF & DM & PH & NPPP & NSPP & HSW & GY \\
\hline DF & 0.014 & 1 & & & & & & \\
\hline DM & 0.204 & 0.53 & 1 & & & & & \\
\hline PH & 0.49 & $0.57^{*}$ & $0.54^{*}$ & 1 & & & & \\
\hline NPPP & $-0.56^{*}$ & 0.39 & -0.17 & -0.08 & 1 & & & \\
\hline NSPP & $-0.78^{* *}$ & -0.34 & $-0.54^{*}$ & $-0.56^{*}$ & 0.29 & 1 & & \\
\hline HSW & $0.54^{*}$ & -0.23 & $0.54^{*}$ & 0.22 & $-0.78^{* *}$ & $-0.59^{*}$ & 1 & -0.42 \\
\hline GY & 0.33 & 0.21 & -0.22 & 0.31 & 0.40 & -0.33 & 1
\end{tabular}

Stepwise regression analyses using grain yield as dependent variable indicated that, hundred seed weight and number of seed per pod were traits which contributed to grain yield. Particularly, $79 \%$ by hundred seed weight and $87 \%$ was contributed together by hundred seed weight and number of seed per pod (Table 13). This illustrates that the improvement in grain yield was achieved by combination of different factors.

Amsal (1994) reported number of grain per meter square alone accounted for most of the variation $(>68 \%)$ in grain yield while number of gain per meter square, 1000-seed weight, plant height, biomass yield collectively contributed for more than $93 \%$ variation in wheat grain yield. Similarly, Tamene (2008) reported that $96 \%$ of the variation in faba bean grain yield was explained by economic growth rate, whereas economic growth rate, number of pod plant ${ }^{-1}$, harvest index and biomass together accounted for $99 \%$ of the variation in grain yield. Tafese et al. (2016) also reported that $84 \%$ of the variation in grain yield of sesame was explained by seed yield per plant, $12 \%$ by harvest index and $96 \%$ was contributed altogether by harvest index and seed yield per plant. 
Stepwise regression analyses showed using hundred seed weight as dependent variable, which is contributed an economic trait in Kabuli type chickpea: number of pods per plant had a declining effect, contributed to the variation among the varieties in hundred seed weight. About $60 \%$ of the variation in Kabuli chickpea seed size was explained by number of pods per plant. Similarly, Tamene (2008) was reported $88.48 \%$ of the variability in thousand seed weight was accounted for by number of pods per plant alone and $92.56 \%$ when both number of pods and grain filling period together.

Table 13. Summary result of selection from stepwise regression analysis of mean grain yield and hundred seed weight as dependent variable and the other traits as independent variable

\begin{tabular}{lll}
\hline & Grain Yield & \\
\hline independent Variable & Regression coefficient (b) & $\mathrm{R}^{2}(\%)$ \\
Hundred seed weight & $-51.37^{*}$ & 0.79 \\
Number of seed per pod & $-4234.56 *$ & 0.87 \\
\hline & Hundred seed weight & 0.60 \\
\hline Number of pods per plant & $-0.97^{* *}$ & 0 \\
\hline
\end{tabular}

\section{Conclusion}

Estimation of the genetic progress achieved through crop breeding helps breeders evaluate the strengths and weaknesses of the breeding program and accordingly devise more efficient strategies for further improvement. This experiment clearly revealed that improved genetic progress was obtained from breeding Kabuli chickpea in Ethiopia for seed size than it was for grain yield. Hundred seed weight was negatively correlated with number of pods per plant and number of seeds per pod. For that reason, the negative relationship between hundred seed weight and with these traits indicates that a compensatory relationship between them. Selection from introductions and hybridization as major breeding methods was successful in improving grain yield as well as different agronomic practices rather than selection from landrace. Therefore, the Kabuli chickpea improvement program needs special attention to compliment seed size and grain yield by using integrated breeding (conventional- crossing works than landrace selection with molecular breeding) approach to make rapid progress in developing chickpea varieties.

\section{ACKNOWLEDGEMENT}

I would like to thank the Ethiopian Institute of Agricultural Research for the permission of leave of absence and financing the study. The Management of Debre Zeit Agricultural Research Center for the administrative support are highly acknowledged for their kind cooperation and encouragement while conducting this work.

\section{REFERENCE}

Alisson Fernando ChioratoI, Sérgio Augusto Morais Carbone, Roland VencovskyI, Nelson da Silva Fonseca Júnior and José Baldin Pinheiro. (2010). Genetic gain in the breeding program of common beans at IAC from 1989 to 2007. Crop Breeding and Applied Biotechnology, 10(4), 329-336

Amsal Tarekegn. (1994). Yield potential of rainfed wheat in the central highland of Ethiopia. An MSc. Thesis Presented to the School of Graduate Studies of Alemaya University.151p.

Cox, T.S., Shroyer,J.P, Ben-Hui, L., Sears, R.G. and Martin, T.J. (1988). Genetic improvement in agronomic traits of hard winter wheat cultivars from 1919 to 1987. Crop Science. 28: 756-761.

CSA (Central Statistical Authority). (2018). Agricultural sample survey, Report on, area and production for major crops (private peasant holdings, meher season). Addis Ababa, Ethiopia.

Demissew Tesfaye. (2010). Genetic gain in grain yield and associated traits of early and medium maturing varieties of soybean [Glycine $\max (\mathrm{L}$.) Merrill]. An M. Sc. Thesis Presented to the School of Graduate Studies of Haramaya University. Ethiopia.

Dewey, D.R. and K.H. Lu. (1959). A correlation and path coefficient analysis of components of crested wheat grass seed production. Agronomy Journal, 51:515-518.

Ersullo Lirie, Habtamu Zeleke and Adugna W. (2016). Genetic Gain in Grain and Oil Yields, Oil Content and Associated Traits of Linseed (Linum usitatissimum L.) in Ethiopia. Greener Journal of Plant Breeding and Crop Science. 4 (3), pp. 057-070.

Evans,L.T. and Fischer, R.A. (1999). Yield Potential: Its definition, measurement, and significance. Crop Science. 39: 1544-1551

Fikre Hagos, Habtamu Zeleke and Bulcha Woyossa. (2012). Genetic Gain in Yield and Yield Related Traits of Groundnut [Arachis hypogea (L.)] in Central Rift Valley of Ethiopia. East African Journal of crop science.6 (2):125- 136.

Follmann, D.N., Cargnelutti Filho, A., Lorentz, L.H., Boligon, A.A., Caraffa, Marcos. and Wartha, Cleiton. (2017). Genetic progress in sunflower crop in Rio Grande do Sul State, Brazil. Genetics and Molecular Research. 16.

Gaur, M. P., Aravind, K. J., and Rajeev, K. V. (2012).A review of impact of Genomic technologies on chickpea breeding strategies. Agronomy, 2: 200-203, India. 
Gemechu Keneni, Endashawu Bekele, Muhammad Imtiaz., Emana Getu, Kifle Dagne and Fasil. Assefa. (2011). Breeding chickpea (Cicer arietnum [Fabaceae]) for better seed quality inadvertently increased susceptibility to adzuki bean beetle (Callosobruchus chinensis [Coleoptera: Bruchidae]). International Journal of Tropical Insect Science, 31, 249-261.

Hailu, T., A. Kamara, B. Asafo-Adjei, B. and Dashiell, K. (2009). Improvement in grain and Fodder yields of early-maturing promiscuous soybean genotypes in the guinea savanna of Nigeria. Crop Science, 49:20372042.

Hulse J.H. (1991). Nature, composition and utilization of pulses. In Uses of Tropical Grain Legumes, Proceedings of a Consultants Meeting, 27-30 March 1989, pp. 11-27. Patancheru, AP: ICRISAT.

Ibrikci, H., Knewtson, S.J.B. and Grusak M.A. (2003). Chickpea leaves as a vegetable green for humans: evaluation of mineral composition. Journal of the Science of Food and Agriculture, 83:945-950.

Jain, M., Misra, G., Patel, R. K., Priya, P., Jhanwar, S., Khan, A. W., Shah, N., Singh, V. K., Garg, R., Jeena, G., Yadav, M., Kant, C., Sharma, P., Yadav, G., Bhatia, S., Tyagi, A. K. and Chattopadhyay, D. (2013). "A draft genome sequence of the pulse crop chickpea (Cicer arietinum L.)." Plant Journal 74(5): 715-729.

Jin, J., Liu, X., Wang, G., M.I .L, Shen, Z.H., Chen, X. and Herbert, S.J. (2010). Agronomic and physiological contributions to the yield improvement of soybean cultivars released from 1950 to 2006 in Northeast China. Field Crops Research. 115: 116-123.

Kanouni, H., Taleei, A. and Okhovat, M. (2011). Aschchyta blight (Ascochyta rabiei (Pass.) Lab. of Chickpea (Cicer arietinum L.): Breeding Strategies for Resistance. International Journal of plant Breeding and Genetics 5:1-22.

Kebere Bezaweletaw, Ketema Belete and Stripichitt, P. (2006). Genetic gain in grain yield and associated agronomic traits in haricot bean [Phaseolu vulgaris L.]. Kasetsart Journal (Natural Science). 40: 835-847.

Kulwal, P. and Mhase, L. (2016). Protein content exhibits a significant positive correlation with seed weight in chickpea germplasm collection. Plant Genetic Resources, 15(3), 283-285.

Mekuria Temtme, Hussen Mohamed and Tesfaye Leta. (2018). Genetic improvement in quality, grain yield and yield associated traits of durum wheat (Triticum turgidum var.durum L.) in Ethiopia. International Journal of Advances in Scientific Research and Engineering .4(8): 2454-8006.

Mihret Yirgu, Firew Mekbib and Setegn Gebeyehu. (2015). Genetic Gain in Lowland Sorghum [Sorghum Bicolor L.Moench] Varieties in Ethiopia. International Journal of Horticulture and Plant Breeding Science. 2(1): 1 -13 .

Morrison, M., H. Voldeng and E. Cober, (2000). Agronomic changes from 58 years of genetic improvement of short-season soybean cultivars in Canada. Agronomy Journal, 92:780-784.

Nurberdy Gummadova, Mesut Keserb, Beyhan Akina, Mustafa Cakmakc, Zafer Mertd, Seyfi Tanere, Irfan Ozturkf, Ali Topalg, Selami Yazard, Alexey Morgounova.(2015). Genetic gains in wheat in Turkey: Winter wheat for irrigated conditions. The crop journal (3) $507-516$.

Ortiz, R., M. Nurminiemi, S. Madsen, O.A. Rognli, A. Bjornstad, (2002). Genetic gains in Nordic spring barley breeding over sixty years. Euphytica. 126: 283-289.

Rajeev K. Varshney, Mahendar Thudi1, Manish Roorkiwal, Weiming He, Hari D. Upadhyaya1, Wei Yang, Prasad Bajaj, Philippe Cubry, Abhishek Rathore, Jianbo Jian, Dadakhalandar Doddamani1, Aamir W. Khan, Vanika Garg, Annapurna Chitikinenil, Dawen Xu, Pooran M. Gaur, Narendra P. Singh, Sushil K. Chaturvedi, Gangarao V. P. R. Nadigatla, Lakshmanan Krishnamurthy, G. P. Dixit, Asnake Fikre, Paul K. Kimurto, Sheshshayee M. Sreeman, Chellapilla Bharadwaj, Shailesh Tripathi 1, Jun Wang, Suk-Ha Lee David Edwards, Kavi Kishor Bilhan Polavarapu, R. Varma Penmetsa, José Crossa Henry T. Nguyen, Kadambot H. M. Siddique, Timothy D. Colmer, Tim Sutton, Eric von Wettberg, Yves Vigouroux, Xun Xu and Xin Liu. 2019. Resequencing of 429 chickpea accessions from 45 countries provides insights into genome diversity, domestication and agronomic traits. Nature Genetics.

Ribeiro, N.D., Filho, A.C., Poersch, N.L., Jost, E. and Rosa, S.S. (2008). Genetic progress in traits of yield, phenology and morphology of common bean. Crop Breeding and Applied Biotechnology. 8: 232-238

Riggs, T.J., Hansan, P.R., Start, N.D., Miles, D.M., Morgan, C.L. and Ford, M.A. (1981).Composition of spring barley varieties grown in England and wales between 1880 and 1980. Journal of Agricultural science, 97:599610.

Sanchez-Garcia, M., Royo, C., Aparicio,N., Juan, A., Martín-Sánchez, and Álvaro, F. (2013). Genetic Improvement of bread wheat and associated traits in Spain during the 20th century. Journal of agricultural science.151, 105-118

Tafese Altaye, Firewu Mekbib and Bulcha Wayossa. (2016). Genetic gain in grain yield potential and associated traits of sesame (Sesamum indicum L.) in Ethiopia. Journal of Biology, Agriculture and Healthcare 6(19), 2224- 3208

Tamene Temesgen, Gemechu Keneni and Hussein Mohammed.(2015). Genetic progresses from over three decades of faba bean (Vicia faba L.) breeding in Ethiopia. Australian Journal of Crop Science. 9(1):41-48. 
Tamene Temesgen, Gemechu Keneni and Hussein Mohammed. (2015). Genetic progresses from over three decades of faba bean (Vicia faba L.) breeding in Ethiopia. Australian Journal of Crop Science. 9(1):41-48.

Tamene Temesgen. (2008). Genetic gain and morpho-agronomic basis of genetic improvent in grain yield potential achieved by faba bean breeding in Ethiopia. M.Sc. Thesis Presented to the School of Graduate Studies of Hawasa University.

Van der Maesen L. G. J., Maxted N. and Javadi Coles F.S.and Davies A.R. M. (2007). Taxonomy of the Genus Cicer Revisited. In: Yadav S.S. (Eds.). Chickpea breeding and management.CAB International, Wallingford, Oxon, UK. pp. 14-47.

Wondimu Fekadu, Habtamu Zeleke and Amsalu Ayana. (2013). Genetic improvement in grain yield and malting quality of barley (Hordeum vulgare L.) in Ethiopia. Ethiopian Journal of Applied Science Technology. 4(2): $37-62$.

Wondimu Fekadu, Habtamu Zeleke and Amsalu Ayana. (2011). Genetic improvement in grain yield potential and associated traits of food barley (Hordeum vulgare L.) in Ethiopia. Ethiopian Journal of Applied Science Technology. 2(2): 43-60.

Wood, J. A. and Grusak, M. A. (2007). "Nutritional value of chickpea." IN: Chickpea Breeding and Management. Yadav, S. S., Redden, R. J., Chen, W. and Sharma, B. Trowbridge, UK, Cromwell Press: 101-142.

Wych, R.D. and D.C. Rasmusson, (1983). Genetic improvement in malting barley varieties since 1920. Crop Science. 23:1037-1040.

Yifru Teklu and Hailu Tefera. (2005). Genetic improvement in grain yield potential and associated agronomic traits of teff (Eragrostis tef). Euphytica, 114: 247-254. 